\title{
ANTIGENS OF BOVINE SEMEN \\ AND THE INFLUENCE OF SPECIFIC RABBIT ANTI-BULL-SEMEN SERUM ON METABOLIC ACTIVITY OF BULL SPERMATOZOA
}

\author{
K. K. MITTAL, * G. W. SALISBURY, $\dagger$ C. N. GRAVES $\dagger$ \\ AND B. A. RASMUSEN* \\ Departments of Animal Science* and of Dairy Science $\dagger$, \\ University of Illinois, Urbana
}

(Received 10th August 1964, revised 11th January 1965)

\begin{abstract}
Summary. Bull semen is very strongly antigenic in rabbits. At least twenty antigenic components were detected by micro-immunoelectrophoresis.

There was a drastic reduction in oxygen uptake, fructose utilization and lactic acid production by bull spermatozoa when mixed with specific antisemen serum. This decreased metabolic activity in the presence of the antisemen was due to death of the spermatozoa as indicated by the live-dead staining technique.
\end{abstract}

\section{INTRODUCTION}

Evidence has been accumulating in recent years that antibodies against semen or washed spermatozoa can prevent fertilization, or may cause embryonic death (Henle \& Henle, 1940; Katsh, 1960; Menge, Stone, Tyler \& Casida, 1962). The earliest observations that spermatozoa are antigenic were reported almost simultaneously by three investigators-Landsteiner in 1899, and Metchnikoff \& Metalnikoff in 1900 (Katsh, 1960). The bulk of evidence in man (Weil \& Rodenburg, 1960; Weil, Kotsevalov \& Wilson, 1956) and in rabbits (Weil \& Finkler, 1959; Weil, 1960) indicates that antigenic material is taken up by the spermatozoa from the seminal plasma. There is also evidence that spermatozoa do possess antigenic properties originating in the spermatozoa themselves (Freund, Thompson \& Lipton, 1955) and spermatozoa and seminal plasma are known to share common antigenic constituents (Pernot \& Szumowski, 1958). Rao \& Sadri $(1959,1960)$ have found at least sixteen antigens in buffalo seminal plasma and seven in spermatozoa, of which four are common to both. In the bovine, evidence has been presented by Gordon \& Hunter (1961) that bull spermatozoa contain at least seven antigens of which at least one is spermatozoa-specific. A report by Hunter \& Hafs (1964) suggesting three spermatozoa-specific antigens in the semen of cattle appeared when this paper was being prepared for publication. Hathaway \& Hartree (1963) have reported four antigens in ram sperm extracts and the same four antigens in ram seminal 
plasma. Metz, Schuel \& Bischoff (1964) have observed that spermatozoa pretreated with univalent antibody have markedly reduced fertilizing capacity.

Thus it appears that species differences exist in the antigenicity of spermatozoa, and that specific antisera somehow reduce the fertilizing capacity of spermatozoa. In view of these observations a series of experiments were undertaken to determine (a) the antigenicity of bull semen in female rabbits and (b) the change in metabolic activity of bull spermatozoa when mixed with rabbit anti-bull semen serum.

\section{Immune sera}

\section{MATERIALS AND METHODS}

All the semen samples for immunization of rabbits were collected from one Holstein-Friesian bull by means of an artificial vagina and were frozen at $-20^{\circ} \mathrm{G}$ soon after collection. Normal sera (Ns) were obtained from four female rabbits (of mixed breeds) prior to immunization and were used as control samples. Each rabbit received injections of $1 \mathrm{ml}$ thawed whole semen and antibiotic mixture (penicillin $\mathrm{G}:$ 10,000 units and dihydrostreptomycin : 4000 $\mathrm{mg}$ ). A fifth doe was injected with antibiotic mixture alone (antibiotic control).

Immunization schedule

$\begin{array}{cclc}\begin{array}{c}\text { No. of } \\ \text { injection }\end{array} & \begin{array}{c}\text { Dose of } \\ \text { semen }\end{array} & \text { Route } & \begin{array}{c}\text { Interval } \\ \text { (days) }\end{array} \\ 1 & 1 \mathrm{ml} & \text { Subcut. } & - \\ 2 & 1 \mathrm{ml} & \text { Intramus. } & 3 \\ 3 & 1 \mathrm{ml} & \text { Intramus. } & 5 \\ 4 & 1 \mathrm{ml} & \text { Subcut. } & 5 \\ 5 & 1 \mathrm{ml} & \text { Subcut. } & 5\end{array}$

Rabbits were bled by heart puncture 8 days after the last injection, and the sera collected were frozen at $-20^{\circ} \mathrm{C}$.

\section{Analysis of immune precipitates}

Antigenic components of bull semen as detected by rabbit antisera were characterized by a modification of the immunoelectrophoresis technique of Grabar \& Williams (1955) and Scheidegger (1955). Slides (2 in. $\times 3$ in.) were prepared using agar gel containing $1 \mathrm{~g}$ Ionagar 2 , and $1 \mathrm{ml}$ of $1 \%$ merthiolate solution in $100 \mathrm{ml} \mathrm{B}-2$ Spinco Barbital buffer (ionic strength 0.05 ). Freshly collected whole semen was frozen at $-20^{\circ} \mathrm{C}$ and thawed at room temperature alternately three times in order to rupture the cells, immediately prior to electrophoresis, and $0.002 \mathrm{ml}$ of the prepared semen was pipetted into each of the two holes on a slide. Electrophoresis was performed for $3 \mathrm{hr}$ at $14 \mathrm{~mA}$ constant current/slide with voltage ranging between 100 and $110 \mathrm{~V}$. Immediately after electrophoresis freshly thawed antisemen serum was pipetted into a trench cut in the middle of the slide between the two holes and was allowed to diffuse at refrigerator temperature $\left(4^{\circ} \mathrm{C}\right)$. Normal sera and antisera were used undiluted and without heat inactivation throughout this study. After 2 days in the refrigerator the gels were set in distilled water for another 2 days, air dried, stained with amido black 10 and photographed. 
Metabolic studies

Bull semen of good initial motility was used and in all cases the ejaculates contained approximately $1.3 \times 10^{9}$ spermatozoa $/ \mathrm{ml}$. Six replications of each of the following treatments were tested:

(1) $0.4 \mathrm{ml}$ semen $+0.8 \mathrm{ml}$ saline.

(2) $0.4 \mathrm{ml}$ semen $+0.4 \mathrm{ml}$ saline $+0.4 \mathrm{ml}$ Ns.

(3) $0.4 \mathrm{ml}$ semen $+0.4 \mathrm{ml}$ saline $+0.4 \mathrm{ml}$ rabbit anti-bull semen serum.

(4) $0.4 \mathrm{ml}$ semen $+0.4 \mathrm{ml}$ saline fructose $+0.4 \mathrm{ml} \mathrm{Ns}$.

(5) $0.4 \mathrm{ml}$ semen $+0.4 \mathrm{ml}$ saline fructose $+0.4 \mathrm{ml}$ rabbit anti-bull semen serum.

The uptake of oxygen was measured by the direct Warburg technique using air as the gas phase (Umbreit, Burris \& Stauffer, 1957); fructose was measured by Mann's modification (1946) of the method of Roe (1934); and lactic acid was determined by the method of Barker \& Summerson (1941). Analysis of variance of the data obtained was used for interpretation of the results.

\section{Immunological studies}

\section{RESULTS}

In tests using micro-agar immunoelectrophoresis, no detectable antibody was found in the serum of a control rabbit immunized with antibiotic mixture, whereas at least twenty antigen-antibody precipitin systems were demonstrable in serum from rabbits immunized with bull semen +antibiotic mixture (Plate 1).

\section{TABLE 1}

EFFECT OF RABBIT NORMAL SERUM AND ANTISEMEN SERUM ON BOVINE SPERMATOZOA DURING 4 HR INCUBATION AT $37^{\circ} \mathrm{G}$

\begin{tabular}{|c|c|c|c|c|c|c|}
\hline \multirow{2}{*}{$\begin{array}{l}\text { Incubation } \\
\text { diluent }\end{array}$} & \multirow{2}{*}{$\begin{array}{c}\text { Oxygen } \\
\text { uptake } \\
\left(\mu l / 10^{8} / 4 h r\right) \\
\text { (Mean } \mathrm{h} \text { (S.E.) }\end{array}$} & \multirow{2}{*}{$\begin{array}{c}\text { Fructose } \\
\text { utilization } \\
\left(\mu g / 10^{8} / 4 h r\right) \\
(\text { Mean } \pm \text { S.E. })\end{array}$} & \multirow{2}{*}{$\begin{array}{c}\text { Lactate } \\
\text { accumulation } \\
\left(\mu g / 10^{8} / 4 \mathrm{hr}\right) \\
\text { (Mean } \pm \text { S.E. })\end{array}$} & \multicolumn{2}{|c|}{ Final motility* } & \multirow{2}{*}{$\begin{array}{c}\% \text { live } \\
\text { (eosin neg.) }\end{array}$} \\
\hline & & & & $\%$ & rate & \\
\hline $\begin{array}{l}\text { Saline } \\
\text { Saline + Ns } \\
\text { Saline + antisemen } \\
\text { Saline fructose + Ns } \\
\text { Saline fructose + } \\
\quad \text { antisemen }\end{array}$ & $\begin{array}{r}28 \cdot 2 \pm 0.58 \\
53 \cdot 7 \pm 3 \cdot 68 \\
8 \cdot 6 \pm 0 \cdot 33 \\
60 \cdot 4 \pm 1 \cdot 41 \\
9 \cdot 3 \pm 0.89\end{array}$ & $\begin{array}{r}254 \cdot 1 \pm 4 \cdot 89 \\
330 \cdot 9 \pm 16 \cdot 41 \\
59 \cdot 6 \pm 12 \cdot 68 \\
170 \cdot 0 \pm 14 \cdot 86 \\
115 \cdot 0 \pm 38 \cdot 91\end{array}$ & $\begin{array}{r}77 \cdot 8 \pm 1 \cdot 07 \\
177 \cdot 5 \pm 36 \cdot 01 \\
26 \cdot 2 \pm 2 \cdot 64 \\
114.8 \pm 7.85 \\
31 \cdot 1 \pm 3.93\end{array}$ & $\begin{array}{c}8.3 \\
56 \cdot 7 \\
0.7 \dagger \\
43.3\end{array}$ & $\begin{array}{l}0 \cdot 8 \\
3 \cdot 5 \\
0 \cdot 2 \\
2 \cdot 8\end{array}$ & $\begin{array}{r}56 \cdot 6 \\
58 \cdot 4 \\
4 \cdot 1 \\
64 \cdot 5\end{array}$ \\
\hline
\end{tabular}

* Visual estimate.

$\uparrow$ All motile sperm in this group in one flask.

\section{Metabolic studies}

The results show a highly significant $(P<0.01)$ reduction in the amount of oxygen consumed, and of lactic acid produced by the spermatozoa in presence of antisemen compared to normal serum controls during the period of $4 \mathbf{h r}$ (Table 1). The two values of the saline control were lower than the serum controls but higher than the antisemen-treated samples, showing that total metabolic activity of spermatozoa is greater in the presence of rabbit normal serum and saline or saline fructose than when mixed with saline alone. 
At the end of 4-hr incubation, samples were tested for the percentage of motile spermatozoa, rate of motility and percentage of live spermatozoa. Averages of observations for each group are given in Table 1.

The results show that the percentage of motile spermatozoa, as well as the rate of motility, was drastically reduced on treatment with rabbit anti-bull semen serum. This was further substantiated by eosin staining by the technique of Lasley, Easley \& McKenzie (1942). The few cells which were alive (in only two of the six flasks containing antisemen-treated samples) may have been in the flask sidearm and thus may not come in contact with the antisemen serum.

A separate test run (Table 2) was made with equal volumes of antisemen and semen, Ns and semen, and saline and semen. No live spermatozoa (as detected by eosin stain) were observed in the antisemen-treated semen samples at the end of $38 \mathrm{~min}$ after mixing. Sperm cells in the presence of Ns or saline showed no such increased mortality, even at the end of $1 \mathrm{hr}$ (total period of test).

\section{TABLE 2}

EFFECT OF ANTISEMEN, NORMAL SERUM (NS) AND SALINE ON SPERMATOZOA AFTER INCUBATION IN A TEST TUBE AT $27^{\circ} \mathrm{C}$

\begin{tabular}{l|c|c|c|c|c}
\hline $\begin{array}{c}\text { Incubation } \\
\text { medium } \\
(1: 1)\end{array}$ & \multicolumn{5}{|c}{ Spermatozoa that were eosin negative $(\%)$} \\
\cline { 2 - 6 } & $8 \mathrm{~min}$ & $18 \mathrm{~min}$ & $28 \mathrm{~min}$ & $38 \mathrm{~min}$ & $\begin{array}{c}\text { over } \\
55 \mathrm{~min}\end{array}$ \\
\hline $\begin{array}{l}\text { Antisemen } \\
\text { NS }\end{array}$ & $59 \cdot 2$ & 40.0 & $10 \cdot 2$ & 0.0 & $\begin{array}{r}0.0 \\
76.8 \\
48.4\end{array}$ \\
\hline
\end{tabular}

\section{DISGUSSION}

The results of this study show that specific anti-bull semen serum significantly reduced the metabolic activity of bovine spermatozoa when the two were mixed. This decrease in the total metabolic activity of all cells in an antisemen-treated sample was due to death of the cells, apparently caused by a strong agglutination reaction between spermatozoa and specific antibodies. Whether the agglutination was due to antibodies reacting specifically with the antigens of the spermatozoa or with the antigens absorbed by the spermatozoa from the seminal plasma was not determined. A pronounced agglutination reaction was, however, clearly visible under the microscope; spermatozoa became quiescent within seconds after making contact with antisemen serum. Neither the normal nor immune sera were heat-inactivated, so that any effects of complement would be expected to be the same for all sera. The toxic effect of normal serum on spermatozoa which has been observed by a number of workers (e.g. Chang, 1947; Edwards, 1960; Spooner, 1964) was not evident, and was most probably obscured by the large numbers of spermatozoa present relative to serum concentration. 
PI..II\% I
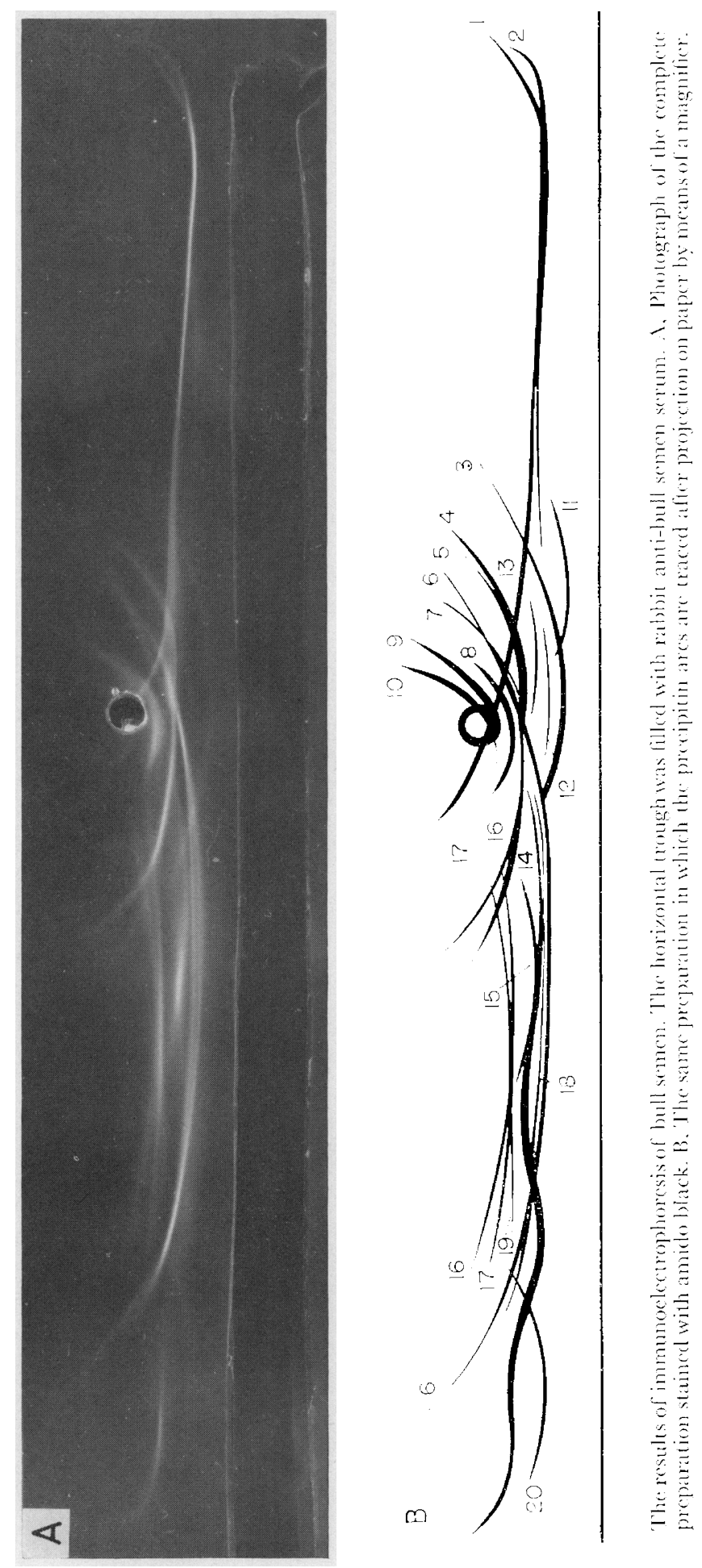
The normal sera of female rabbits as compared to saline controls did not reduce the activity of bull spermatozoa; motility was higher at the end of the 4-hr incubation period in those samples treated with saline+ Ns than in those treated with saline alone (Table 1). This difference in physical activity (nearly the same proportion of the cells were alive at the end of the period) could explain the differences observed in utilization of oxygen. There was also an increased fructose utilization, lactate accumulation and higher final motility present in the saline + Ns-treated samples as compared to the saline fructose+ Ns-treated samples. The stimulatory effect of Ns and the somewhat less stimulatory effect of fructose in relation to it, were not investigated further.

Immunologically, bull semen is very strongly antigenic in female rabbits; no adjuvant or prolonged series of immunizations was required to get a titre of antibodies four times higher than was necessary for detectable precipitation reactions.

\section{REFERENCES}

BARKER, S. B \& Summerson, W. H. (1941) The colorimetric determination of lactic acid in biological material. 7. biol. Chem. 138, 535.

Chang, M. C. (1947) The effect of serum on spermatozoa. F. gen. Physiol. 30, 321.

EDwARDs, R. G. (1960) Complement-fixing activity of normal rabbit serum with rabbit spermatozoa and seminal plasma. F. Reprod. Fertil. 1, 268.

Freund, J., Thompson, G. E. \& Lipton, M. M. (1955) Aspermatogenesis, anaphylaxis, and cutaneous sensitization induced in the guinea pig by homologous testicular extract. $\mathcal{F}$. exp. Med. 101, 591 .

Gordon, M. J. \& Hunter, A. G. (1961) Spermatozoa-specific antigens in the bovine. F. Dairy Sci. 44, 1182 .

Grabar, P. \& Williams, C. A. JR. (1955) Méthode immuno-électrophorétique d'analyse de mélanges de substances antigéniques. Biochim. biophys. Acta, 17, 67.

Hathaway, R. R. \& HartreE, E. F. (1963) Observations on the mammalian acrosome: experimental removal of acrosomes from ram and bull spermatozoa. F. Reprod. Fertil. 5, 225.

Henle, E. \& Henle, G. (1940) Spermatozoal antibodies and fertility. II. Attempt to induce temporary sterility in female guinea pigs by active immunization against spermatozoa. $\mathcal{7}$. Immunol. 38, 105.

Hunter, A. G. \& Hars, H. D. (1964) Antigenicity and cross-reactions of bovine spermatozoa. $\mathcal{J}$. Reprod. Fertil. 7, 357.

Katsh, S. (1960) Antigen-antibody reactions in relation to reproduction. Supplement to F. Dairy Sci. 43, 84 .

Lasley, J. F., Easley, G. T. \& McKenzie, F. F. (1942) A staining method for the differentiation of live and dead spermatozoa. I. Applicability to the staining of ram spermatozoa. Anat. Rec. 82, 167.

MANN, T. (1946) Studies on the metabolism of semen. III. Fructose as a normal constituent of seminal plasma. Site of formation and function of fructose in semen. Biochem. F. 40, 481.

Menge, A. C., Stone, W. H., Tyler, W. J. \& Casida, L. E. (1962) Immunological studies on fertility and sterility. IV. Fertility of cattle and rabbits inseminated with semen treated with antibodies produced against semen, spermatozoa and erythrocytes. F. Reprod. Fertil. 3, 331.

Metz, C. B., Schuel, H. \& Bischoff, E. R. (1964) Inhibition of the fertilizing capacity of sea urchin sperm by papain digested, non-agglutinating antibody. J. exp. Zool. 155, 261.

Pernot, E. \& Szumowski, P. (1958) Etude électrophorétique et immunoélectrophorétique des protéines du plasma seminal de taureau. Bull. Soc. Chim. biol. (Paris), 40, 1423.

RAO, S. S. \& SADRI, K. K. (1959) Immunological studies with human semen and cervical mucus. Proc. VIth int. Conf. Planned Parenthood Fed., London, p. 313.

RAO, S. S. \& SADRI, K. K. (1960) The antigenic composition of buffalo semen. F. comp. Path. 70, 1.

RoE, J. H. (1934) A colorimetric method for the determination of fructose in blood and urine. $\mathcal{F}$. biol. Chem. 107, 15.

Schemegger, J. J. (1955) Une micro-méthode de l'immunoélectrophorèse. Int. Arch. Allergy, 7, 103.

SPOONER, R. L. (1964) Cytolytic activity of the serum of normal male guinea pigs against their own testicular cells. Nature, Lond. 202, 915.

Umbreit, W. W., Burris, R. H. \& Stauffer, J. F. (1957) Manometric techniques, 3rd edn. Burgess, Minneapolis. 
WEIL, A. J. (1960) Immunological differentiation of epididymal and seminal spermatozoa of the rabbit. Science, 131, 1040.

WEIL, A. J. \& FINKLER, A. E. (1959) Isoantigenicity of rabbit semen. Proc. Soc. exp. Biol., N.Y. 102, 624.

Weil, A. J., Kotsevalov, O. \& Wilson, L. (1956) Antigens of human seminal plasma. Proc. Soc. exp. Biol., N.Y. 92, 606.

WEIL, A. J. \& RoDenburg, J. M. (1960) Immunological differentiation of human testicular (spermatocele) and seminal spermatozoa. Proc. Soc. exp. Biol., N.Y. 105, 43. 